\title{
On Public Security Bureau Police Resources Redistribution
}

\author{
Wang Gang ${ }^{1}$, Wang Yuzhi ${ }^{2}$ \\ 1.2 Department of Investigation, Hubei University of Police, Wuhan Hubei ,430000, China
}

\author{
Keywords: Public security bureau; Police; Redistribution
}

\begin{abstract}
To consolidate the state power, the basic role of grass-roots public security bureaus should be given full play to fight against crimes and maintain social stability and serve the people. At the basic work stage of modernized public security, we should more give full play to the job level, comprehensively improve the basic quality level of basic-level police and fundamentally improve the level of law enforcement. Police team construction and development may achieve national security and improve social stability. Establish police authority, promote police redistribution, be close to the people, and provide security services more directly. Police redistribution, as the focus of modern public security bureau reform, has certain significance.

Police redistribution is an important measure to invest a lot of authority fine police and equipment in the first team in current complex security environment to improve grassroots police fighting capacity and make public security bureau to exert its functions effectively. In our country's public security department grass-roots construction standardization process, pay attention to the good job of streamlined authority. The grass-roots work emphasizes actual combat and realizes the reform development of police redistribution. In modern development environment, public security departments pay more attention to bureau models' streamlined application. It fundamentally secures the full implementation of basic public security work and provides basic guarantee for public security bureau police redistribution.
\end{abstract}

\section{THE MANIFESTATION OF PUBLIC SECURITY BUREAU POLICE REDISTRIBUTION}

A. Public security bureau agencies and departments are overstaffed

Public security bureaus in our country at present is relatively overstaffed and there is serious overlapping phenomenon between departments. From the perspective of management theory amplitude, it can be seen that managers can barely implement control subordinates directly. If this is not in the realm of management personnel's management directly, it will directly lead to the decrease of management efficiency [1]. Public security bureau organization department appears in increasingly complex public working environment and gradually increasing scale environment. The former management department has limited management range. With the increasing workload, new management level has to be constantly added. In previous institutional reform, organization sacking and personnel sacking have been implemented, but the effect is not obvious.

B. Greater pressure to grassroots

Part of public security bureau police redistribution is mainly to put ill-functional organization and some sick police to the grass-roots level. And there are capable police forces in the bureau, so the current situation of police redistribution is not optimistic. Police salary has a larger difference relatively. In California in the United States, sworn officers earn about $\$ 4000$ a month or so. Under normal circumstances, after four years of work, they would be promoted to level two police officers, and the monthly salary will be higher, at about $\$ 5000$ a month. And civilian police officers' monthly salary is relatively less, at about $\$ 2800$. First line police has better treatment. For Hong Kong police, police configuration is like that related police officers account for $91 \%$ and supervision police officers account for $9 \%$. Police redistribution, as a kind of common phenomenon, is difficult to beat serious illegal crime molecules' bad behavior. Police redistribution process makes the police in white-collar stage, and in office working process, there is no business contact at the base. With more exclusive thought, the police are difficult to function. Bureau's unhealthy work style penetrates at the grassroots level. Bureau's unhealthy work style is relatively idle. In police 
redistribution stage, affairs at the grass-roots level are difficult to get processed. Grass-roots work process has a lot of working stress and there is police duty escape thought.

\section{Police redistribution becomes a mere formality}

Public security bureau police redistribution work is hard to be implemented effectively. There is not just list redistribution form, and at the same time, there is also a form of fund redistribution. List redistribution is mainly the working process of the base line, which has always been done by invisible man. Fund redistribution process mainly has a relatively specific system requirement in the adjusting promotion stage of public security bureau, but the selection of cadres is always from the grassroots level and the police work without output after getting at the grass-roots level. They are just to mix some political capital. Public security bureau grassroots level construction is hard to avoid interests, and police officers have poor sense of responsibility. Relatively, police redistribution has a shorter propulsion time. The police have limited work ability, inadequate personnel and fuzzy stipulation [2]. When being out of grassroots, the grass-roots organizations' work enthusiasm is not high, and the police's work state is having right without post, hoping for a better job, they would obtain undeserved interests. Public security bureaus' police redistribution in our country often lacks long-term police redistribution planning. Public security bureau police redistribution's current situation is not optimistic. Once encountered police work, because the police have different opinions, different personality and actual working condition, a lot of police have reluctant psychological state and this makes police redistribution only become a mere formality.

\section{THE IMPROVEMENT WAYS OF PUBLIC SECURITY BUREAU POLICE REDISTRIBUTION}

\section{A. Strengthen police discipline and fully promote police redistribution}

The development of public security bureau police redistribution needs to timely solve the thought problem and thought education work may fundamentally and comprehensively promote greatly the ideological work at the grass-roots. Police redistribution avoids the rebound and resilience state. China's public security bureaus should more make first team police role into full play. Set up specialized work organization to improve the management awareness of organizational leadership from the source. Establish awareness of law enforcement for the people, and the basic people-oriented idea should be even more manifested to reflect state police's work for the people. In the process of following the principle of job rotation and fairness, implement the fundamental process of services for the people [3]. Chinese traditional culture has main characteristics of focusing on human feelings and the relationship. In law enforcement process, grassroots police also has the basic process of relationship as well as human feelings. And grassroots police security often need to be combined with talent training to further deepen police configuration and improve the effectiveness of work arrangement so as to advance police redistribution. Police shortage problem is more serious, so public security department needs close union with police recruitment in order to supplement grass-roots police effectively and improve urban street police alarm rate. Inside the public security bureau, attrition should be adopted in order to implement scientific combination and optimization for police.

Police downtown is one of the important measures based on government reform. The reform has entered the crucial stage. The next step reform goal of public security has common understanding with the society from all walks of life. That is to increasingly promote the development of government itself reform, thus effectively promote the long-term development of productivity. In public service government, it belongs to main provider, so in the process of construction and development, we must pay attention to reduce administrative costs and achieve optimum service for the public on the basis of maximally reducing the resource utilization. Under the request, the government has to focus on the analysis of resource control and economy in order to be able to provide the best service for the people [4]. Public security bureaus are one of the government departments, and the main task is to ensure the safety of social public. Under the rapid economic development environment, crime and crime forms are constantly changing, which also brings new challenges to public security department. The coordination between government reform requirements and social development needs becomes a major problem. Government may not give 
substantial increase resources to public authorities, so in this environment, it is necessary to increase the internal potential digging to finish all the work of public agencies. This factor also is the main external driver of police redistribution.

B. Improve the public security bureau law enforcement mechanism and do a good job of police redistribution

The improvement of public security bureau law enforcement mechanism needs more clear indicators to constantly perfect police redistribution assessment mechanism. In police redistribution process, combined with the basic conditions of public security bureau department, as far as possible increase the number of grassroots police and enhances unceasingly the basic-level police quality. At the same time of strengthening basic facilities construction, timely repair and promote large-scale construction and make fundamental reform and development. The development process of grass-roots level police work development needs timely improvement of public security personnel working environment. Equipment improvement process guarantees the stable investment of grass-roots army vehicles and strengthens grass-roots police equipment supply as much as possible. Law enforcement rights are intensifying. Grassroots police must timely and effectively solve problems and difficulties encountered in law enforcement. The training course should focus on case guidance. Establish forensic and improve the system of community policing. Intensify law enforcement and report the related cases in a timely manner, thus enhance protective consciousness ego and as far as possible improve law enforcement quality ability. In a global and strategic development point of view, considering the basic work and policy guidance, optimize the public security bureau law enforcement system. Tilt at the grass-roots level in the construction of system implementation to realize work down of public security work center. The fundamental guarantee of police redistribution is to maximally increase grass-roots instance and fully inspire grass-roots vitality.

To fully implement police redistribution work, we should implement police supervision accountability system. Pay attention to check supervision work and combined with the conditions of false police investigation, make first line police officers investigation. Avoid slide pass and eliminate traditional thoughts of once and for all. Tracking and investigation work should best spot check work and secure work implementation. Police redistribution incentive mechanism's security improvement should pay attention to political treatment actively guide and strengthen the reward for first line police. Commend timely typical behavior in the process of law enforcement. Give priority to membership promotion work of the grassroots police. Make grassroots police work combined with demobilized army cadre situation. Reasonably establish public security bureau institution and avoid the breeding of drifting along thought. Pay attention to economic interests' induction and improve grass-roots police wages material benefits to motivate grassroots police to do police work. Modern economic development in our country is in economy transition stage. There are many social contradictions. For traditional policing management process, the inadequate grass-roots level and crowded management level police results in serious waste of resources. Under the environment of policing mechanism reform, gradually implement organization small grassroots mode, then the previous upside-down triangle police configuration structure will be maximally improved.

\section{Improve police redistribution safeguards mechanism and long-term mechanism}

Police redistribution safeguard mechanism in the process of construction should pay attention to the effective cooperation with the government to really achieve grassroots public authority reform. Grass-roots level security fund guarantee system must be perfected to realize the effective improvement of grass-roots departments' office conditions. Priority principle's application in grass-roots departments is to timely give welfare to the first line police and reduce workload. Police use examination and approval system and calling system for non-police activities must also be gradually standardized. Maximally improve work enthusiasm of the grassroots public security department and simplify complex report file. In the process of complex law enforcement working procedure reform, implement the specification and reform of the related appraisal system [5].

Young police training process at the grassroots level should be about two years of exercise. Make 
strict rules for loaned personnel program to safeguard police legitimate rights and interests, improve grassroots police work enthusiasm, and improve the contribution proportion of grassroots police in public security institutions. Achieve an effective reward to merits and fully arouse the enthusiasm of grassroots police fundamentally. The construction of police redistribution assessment mechanism needs the combination of operational mechanism and guarantee mechanism. Combined with education system and the application of incentive mechanism, fundamentally implement police redistribution work.

Therefore, the effective integration of resources will help the effective reform of the problems existing in traditional public security department. Strictly implement the work style of police discipline enforcement and law enforcement for the people so as to truly achieve strong police and people protection. Raise the credibility of police's public security in public. Effectively improve the long-term existing problems of separation and incorporation in grass-roots public security departments. Truly realize the normalized development of public authority. Innovate management mode and lay good foundation for the implementation of police redistribution to ensure the stability of the society.

\section{CONCLUSION}

The comprehensive promotion of public security bureau police redistribution needs to fully arouse the enthusiasm of public security bureau work. Public security bureaus work, at the same time, needs to perfect system construction and innovation of policing operating mechanism so as to promote the all-round development of basic infrastructure in the construction of public security basic work process.

\section{REFERENCE}

[1] Li Yaxin. "Police redistribution" type policing reform review ---- Henan police reform for sample analysis [J]. Journal of Sichuan Police Academy, 2011, 23 (5) : 81-88.

[2] Ning Jinlong. Comprehensively deepen reform and promote public security bureau's core strength [J]. Journal of Hebei Province Public Security Police Vocational College, 2014, 14 (4) : 5-7.

[3] Yang Peng. Police redistribution basic condition analysis [J]. Journal of Guizhou Police Vocational College Journal, 2012, 24 (2) : 124-128.

[4] He Xiaoliang, Liu Jielin. Grassroots police shortage problem analysis and countermeasures study under the guide of actual combat [J]. Journal of Law and Society, 2015, 07(8) : 193-194.

[5] Liu Hongbin, Deng Chun. Wuhan police redistribution and policing mechanism innovation research under dynamic social environment [J]. Journal of Hubei Economy Academy (Humanities and Social Science Edition), 2014, 11 (12) : 64-65. 